\title{
Extent of Use of ICTs by Fish Farmers in Isoko Agricultural Zone of Delta State, Nigeria
}

\author{
Aphunu, A. and Atoma, C. N. \\ Department of Agric. Extension and Management, \\ Delta State Polytechnic, Ozoro. \\ Corresponding E-mail- tonyaphunu@yahoo.co.uk
}

\begin{abstract}
The study examined the extent of use of ICTs by fish farmers in Isoko agricultural zone of Delta State. Data obtained from 60 respondents purposively selected for the study, were summarized using percentage, mean score and correlation coefficient. The respondents were within the mean age of 45 years and males (60\%) were more involved in fish farming than their female counterparts; they were mainly small scale fish farmers. The respondents were well aware of and used the telephone (GSM), television and radio for their contacts and enquiries, report preparation and information search. However, use of ICT facilities was constrained by the problem of maintenance, low level of production and rural poverty. Training to increase technical efficiency of farmers on ICT use and maintenance, and establishing appropriate policies to reduce rural poverty remain instrumental towards ICTs use by fish farmers.
\end{abstract}

Keywords: Delta State, extent, fish farmers and ICT use.

\section{INTRODUCTION}

Fisheries offer a key entry point to reach millions of poor people of Africa, including Nigeria to assist in increasing people's income, improving the nutrition and health of families and becoming active agents of economic development and social change (Bene and Hecks, 2005). Ifejika, Akinbile, Ifejika and Oladeji (2008) notes that experience confirmed the positive impact of aquaculture in countries like China,Vietnam, Philipines, Bangladesh and India. Ayodele and Ajani (1999) reported that fish farming is now producing half of the fish produced in Nigeria; while Akinyemi (1998) highlighted the cost effectiveness of fish farming in meeting the demand for fish in the country rather than depending on fish imports. Nigeria is reported to have aquaculture potential which constitutes $75 \%$ of $923,768 \mathrm{~km}^{2}$ of the landmass and 14 million hectares of inland freshwater, but less than $1 \%$ is utilized for fish production (Ugwumba and Ugwumba, 2003; and Food and Agricultural Organization (FAO), (2005). The report further reveals that aquaculture is dwarfed by fish importation, an indication of poor exploitation of aquaculture resources capable of producing over 3 million tonnes of fish to meet domestic demand and 
excess for export (Ifejika et al, 2008). Thus, despite the wide acceptance of fish farming as an income generating activity, its contribution to total domestic fish production in the country has not met the target (Akinyemi, 1998). This is basically due to lack of technological know-how by fish farmers and prospective entrepreneurs.

The use of aquaculture technologies to strengthen production has proven potentials to revising the trend of fish importation. Applying proven technologies will increase production of small-scale operators that constitute $80 \%$ of global fish farmers (New Partnership for African Development (NEPAD), 2005; Gupta, 2006). Information on improved aquaculture technologies and its resultant effect on productivity and income of fish farmers need to be investigated. The search for an effective strategy for agricultural development calls for adequate use and application of ICTs, especially computers and the Internet, which are considered as among the principal drivers of economic growth and development worldwide (Abubakar and Abdulahi, 2009). Emphasis is being placed on the use of ICTs in boosting agricultural production among farmers. Farmers who are hooked up to new technologies fare better (Adejo and Haruna, 2009). ICT plays essential role in poverty alleviation by providing powerful tool to rural farmers and other citizens to grow their business and create new opportunities and delivery of services to rural areas. Fish farmers need information to enhance agricultural management, research and development (Nkwocha, Ibeawuchi, Chukwueke, Azubuike and Nkwocha, 2009). ICTs promote access to and sharing of information in agriculture and allied fields. ICTs include the use of radio, television and computer/Internet, global system of mobile telecommunication (GSM) and the other fixed telephone network, fax, e.t.c.

However, while ICTs boosts information supply on improved farm technologies and the resultant effect on productivity and income of farmers, the great challenge is that most Nigerian farmers are illiterates, living in the rural areas, hence they have no knowledge of the use of ICTs facilities like computer and Internet (Omotayo, 2005). Technical Centre for Agriculture (CTA) Spore (2004) report notes that the number of farmers who are hooked to new technologies through ICTs are few and far between. This is further compounded by vicious cycle of poverty that continues to hamper the capacity of rural farmers to improve their standard of living. Assessors of rural ICT development have not only established a number of constraints to ICT development in rural areas, but also have the general consensus that the current trend of ICT development tends to be biased against the rural population (FAO, 2004). Nkwocha et al (2009) in their study found out that, there were more prevalent factors limiting access to ICT in Okigwe zone (predominantly in the rural areas) of Imo State. Similarly, Shah (2009) reported that, access to broadband Internet services is substantially low in rural areas and poor urban neighbourhoods of many developing countries than in the metropolitan urban.

Therefore, the need to bridge the current digital divide between the rural and the urban areas in order to help improve the living standard of farmers and agricultural production call for the adequate knowledge of the extent of use of ICT by farmers in the study area. The study answers the following research questions 
bordering on the use of ICT by fish farmers in the study area: Do fish farmers have access to ICT facilities in the area? What factors constrain their access to and use of ICT facilities? What activities of fish farming do fish famers use ICT facilities? What demographic variables influence the use of ICT facilities?

The broad objective of the study was to assess the extent of use of ICTs by fish farmers in Isoko agricultural zone, Delta State. Specifically, the study was designed to:

(i) determine the access of fish farmers to ICTs in the study area;

(ii) identify areas of ICTs use by fish farmers;

(iii) ascertain problems in gaining access to ICTs by fish farmers; and

(iv) assess the socio-economic variables associated with ICTs usage.

\section{METHODOLOGY}

The study was carried out in the Isoko agricultural zone, within the DeltaSouth agro-ecological zone of Delta State. The zone comprises two Local Government Areas (LGA) namely, Isoko South and Isoko North and with a population of over 294,991 people (National Population Commission, 2006). The area, like all other parts of the Niger Delta area of Nigeria, has a humid subequatorial climate with long wet season lasting from March to October. The vegetation is mainly decidous and evergreen forest with scanty mangrove forest. The main occupation of the area is farming and fishing. Ten communities, namely Igbide, Olomoro, Uzere, Irri, Aviara, Owhe, Ellu, Ofagbe, Emevor and Ozoro known for fish farming were purposively selected for the study. Six (6) fish farmers were selected through simple random sampling technique, making a total of 60 fish farmers for the study. A structured interview schedule was used to collect relevant information from the respondents. The dependent variable for the study was "Extent of ICT use" by fish farmers. Extent of use was defined as the actual activity where ICT was used by the respondents. To determine the extent of ICT usage, twenty one activity areas (believed to enhance and boost fish production) were identified and respondents were asked to indicate which of the activities they had used. For any activity where a respondent used ICT, a score of one was given. The total score for activity area where ICT was employed was expressed as a percentage of the total number of respondents involved.

To determine respondents' frequency of ICTs use, a three-point Likert-type scale with nine items was utilized. The response options ranged from "not at all"= 1 ; "sometimes" $=2$ to "all the time" $=3$. The values were added to obtain 6 , which was divided by 3 to get a mean score of 2.0. Mean scores of 2.0 or above were classified as frequently used, while scores less than 2.0 were regarded otherwise. Respondents' perceived constraints to ICTs use were measured on a three-point Likert-type scale with 12 items, and the response options ranged from "not serious" $=1$; "serious" $=2$ to "very serious" $=3$. A mean score of 2.0 was obtained; mean scores 2.0 and above were regarded as serious constraints and otherwise. Percentage was used to summarize data relating to objectives1 and 2. Mean score 
was used for objectives 3 while Pearson Product Moment Correlation (PPMC) was used for objective 4.

\section{RESULTS AND DISCUSSION}

\section{Socio-Economic Characteristics}

Data in Table 1 show that majority (83.3\%) of the respondents were males within the age of 41-55 years. This is consistent with the findings of Ifejika et al (2008), and Ifejika and Ayanda (2006). By implication, youth's involvement (30\%) in fish farming is low and may pose a threat to the supply of fish food in the future. Majority (66.7\%) of the respondents were married, a trend which implies that most of them have family responsibilities that need financial commitments. This result also tallies with the findings of Ifejika et al (2008). About $45 \%$ of the respondents had secondary education, $40 \%$ had tertiary education and $5.0 \%$ were illiterates. The level of educational attainment is sufficient to support adoption of technology through information sharing and distribution, as reported by Ridler and Hashamunds (2001).

Table 1 further reveals that $70 \%$ of the respondents had less than five year experience in fish farming whereas $18.3 \%$ had between 6 to 10 years. The implication is that the respondents are less experienced and have higher likelihood of risk in their occupation. Experience is a risk management factor and is considered to be low among new farmers (especially in aquaculture) (Rider and Hashamunda, 2001). Response on the number of ponds shows that the respondents were small scale fish farmers. A majority (63.3\%) have between 1 and 5 fish ponds while only $25 \%$ had between 6 and 10 ponds. The finding is in agreement with Olopade, Taiwo and Odunaya (2005). 
TABLE 1: Percentage distribution of respondents selected socioeconomics characteristics

\begin{tabular}{lcc}
\hline \multicolumn{1}{c}{ Variable } & Percentage $(\mathbf{n}=\mathbf{6 0})$ & Mean \\
\hline Age & 30.0 & 45 \\
$25-40$ & 45.0 & \\
$41-55$ & 20.0 & \\
$56-70$ & 5.0 & \\
Above & & \\
Sex & 83.3 & \\
Male & 16.7 & \\
Female & & \\
Marital Status & 33.3 & \\
Single & 66.7 & \\
Married & & \\
Education & 5.0 & \\
No formal education & 8.3 & \\
Primary & 45.0 & \\
Secondary & 40.0 & \\
Tertiary & 1.7 & \\
Adult education & & \\
Fish farming experience & 70.0 & \\
Less than 5 years & 18.3 & \\
$6-10$ years & 11.7 & \\
Above 10 years & & \\
Number of fish ponds & 63.3 & \\
$1-5$ & 25.0 & \\
$6-10$ & 11.7 & \\
Above 10 &
\end{tabular}

Source: Field Survey (2010)

\section{Fish farmers' access to ICT}

Table 2 shows that majority (95\%) of the respondents had access to radio and telephone (fixed and GSM) while $93.3 \%$ of them had access to television. Respondents' access to internet, computer based communication devices, e.t.c. was low. This result tallies with the findings of Owen (2008) in his USAID ICT4D program report where he asserted that over $50 \%$ of the world population have access to, or uses a mobile phone and only $5 \%$ of the world's population have access to or uses broadband Internet. The result implies that conventional ICTs (radio, television and telephones) still remain the most accessible ICTs in the study area. 
TABLE 2: Percentage distribution of respondents on access to ICTs

\begin{tabular}{lc}
\hline Variables & Access (\%) \\
\hline Radio & 95.0 \\
Telephones (fixed and GSM) & 95.0 \\
Television & 93.0 \\
Internet & 36.7 \\
Computer/Computer based communication & \\
devices & 28.3 \\
E-mail & 21.7 \\
Print media & 15.0 \\
Compact Disc Read only Memory (CD-ROM) & 11.7 \\
Fax & 1.7 \\
\hline
\end{tabular}

*Multiple responses

Source: Field Survey (2010)

\section{Most frequently used ICT}

Table 3 showed that the telephone (mean=2.75), television (mean=2.70) and radio (mean=2.63) were the most frequently used ICT facilities among fish farmers. The result is in agreement with the findings of Arokoyo, (2003) that radio and television remained the major ICTs used for extension service delivery especially in the rural areas. Similarly, Adejo and Haruna, (2009) stated that these classes of ICTs facilities are ideal for rural areas, cheap to set up, easy to use and filling vital needs. 
TABLE 3: Mean distribution of respondents on frequently used ICTs

\begin{tabular}{lll}
\hline \multicolumn{1}{c}{ Variable } & Mean \\
\hline Telephones & 2.75 \\
Television & 2.70 \\
Radio & 2.63 \\
Computer/Computer based & 1.97 \\
Internet & 1.82 \\
E-mail & 1.70 \\
C.D-ROM & 1.42 \\
Print media & 1.40 \\
Fax & 1.35 \\
\hline
\end{tabular}

Source: Field Survey (2010)

\section{Use of ICT by Fish farmers}

Responses in Table 4 show area of use of ICTs. The result showed that all the respondents (100\%) use the GSM for contacts and inquiries. Fish farmers from the area confirmed that with mobile phones, they had access to critical information (on fish breeds, feeds and management), and made inquiries about market predictions and when buyers were coming from the cities so that they could plan harvesting programme. The result was expected since the GSM is handier, fast and less expensive compared to other modern ICT facilities. The table further show that $25 \%$ of the respondents used computer for word processing, while $21.7 \%$ used it for report preparation. Only $21.7 \%$ used the internet for information search. Furthermore, the result confirm the fact that application of ICTs in other areas such as sending mails $(8.3 \%)$, fish ration formulation $(5.0 \%)$ and advertisement $(5.0 \%)$ were negligible. 
TABLE 4: Distribution of respondents on areas ICTs use

\begin{tabular}{llc}
\hline \multicolumn{1}{c}{ Variable } & \multicolumn{1}{c}{ Activities of ICT usage } & Percentage \\
\hline GSM & Contact/inquiries & 100 \\
Computer & Control & - \\
& Type letters & 25.0 \\
Internet & Prepare reports & 21.7 \\
& Search information & 21.7 \\
E-Mail & Have website & 3.3 \\
Spread sheet & Receive mail & 8.3 \\
& Send mail & 8.3 \\
& Enter data & 6.7 \\
& Mathematics operation & 5.0 \\
Specialized programs & Create chart & - \\
& Prepare income/expenditure & 6.7 \\
& Pay roll & 5.0 \\
& Financial management & 6.7 \\
& Ration formulation & 5.0 \\
Radio and Television & Data analysis & 1.7 \\
CD-ROM & Human resource management & 1.7 \\
Others & News/farm information & 3.0 \\
\hline
\end{tabular}

Source: Field Survey (2010)

\section{Constraints to ICT usage by fish farmers}

Data on Table 5 show that lack of government enabling policy (mean=2.18) is one of the main pressing constraints against effective utilization of ICTs in the study area. Maintenance problems (mean $=2.10)$, low scale of fish production (mean=2.08) and rural poverty (mean=2.05) were also identified as serious constraints to ICTs use by fish farmers. Nkwocha et al (2009) stated that government's low level of assistance to ICTs infrastructural provision and absence of any policy to encourage farmers gain ICT education pose threat to agricultural development. 
TABLE 5: Mean distribution of respondents on constraints to the use of ICTs

\begin{tabular}{lc}
\hline \multicolumn{1}{c}{ Constraints } & Mean \\
\hline Lack of enabling government policy & 2.18 \\
Potential problems of ICT facilities maintenance & 2.10 \\
Relatively low scale agricultural production & 2.08 \\
Rural poverty & 2.05 \\
Insufficient financial resources & 1.90 \\
Lack of skills to operate ICTs facilities & 1.97 \\
High cost of acquiring ICTs facilities & 1.83 \\
Lack of awareness/knowledge about the importance & 1.82 \\
of ICT & 1.78 \\
Lack of regular power supply & \\
Emerging syndrome of seeing ICT as an evolving technology 1 & 1.62 \\
the youths & 1.53 \\
Lack of training on ICT & 1.53 \\
\hline Limited number of ICT facilities &
\end{tabular}

Source: Field Survey (2010)

\section{Relationship between respondents' characteristics and ICT use}

Table 6 shows education is significantly related to the use of computer/computer based communication $(r=0.540, \quad p<0.01)$, internet $(r=0.383 . p<0.01)$, e-mail $(r=0.312, p<0.05)$ and print media $(r=0.289, p<0.05)$. The table further shows that experience is significantly associated with the use of computer $(r=0.266, p<0.05)$, while the number of fish ponds owned was significantly associated with the use of radio $(r=0.324, p<0.05)$, computer $(r=0.270, p<0.05)$ and e-mail $(r=0.286, p<0.05)$. Educational levels of respondents enhance their comprehension of technical information and make them able to manipulate the information (Akinbile, 2003) and hence influence their choice and use of ICTs facilities, especially the complex ones. The more the numbers of fish ponds the respondents have, the more the propensity to seek for information for increased production and management and also the use of different ICTs facilities. 
TABLE 6: Relationship between respondents' characteristics and use of ICTs

\begin{tabular}{|c|c|c|c|c|c|c|c|c|}
\hline Variable & Radio & T.V & $\begin{array}{l}\text { Tele- } \\
\text { phones }\end{array}$ & $\begin{array}{l}\text { Com- } \\
\text { puters }\end{array}$ & Internet & E-Mail & $\begin{array}{l}\text { Print } \\
\text { Media }\end{array}$ & Fax \\
\hline Age & 130 & -0.135 & .029 & 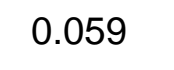 & 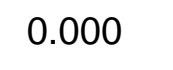 & 0.151 & .137 & -0.1 \\
\hline Education & -0.213 & -0.178 & -0.126 & $-0.540^{* *}$ & $-0.383^{\star *}$ & $-0.312^{*}$ & $-0.289^{*}$ & -0.10 \\
\hline Experience & -0.119 & 0.001 & -0.117 & $-0.266^{*}$ & -0.061 & -0.181 & 0.234 & -0.14 \\
\hline Number of ponds & $-0.324^{*}$ & 0.109 & -0.182 & $0.270^{*}$ & -0.181 & $-0.286^{*}$ & -0.144 & -0.10 \\
\hline
\end{tabular}

${ }^{*}$ Significant at 0.01 level

*Significant at 0.05 level

Source: Field Survey (2010).

\section{CONCLUSION}

The findings of this study show that fish farmers' access to ICTs in the study area is still mostly conventional, since majority of them depend on the media (radio and television) and the telephones (GSM) for their agricultural information needs, contacts and enquiries, report preparation and information search. However, lack of enabling government policies on ICTs, relative low level of fish production, maintenance problems and rural poverty pose serious constraints to ICTs use by fish farmers. It is being recommended that a positive policy change by government towards promoting ICTs education and provision of infrastructures to consolidate farmers' training be made, to enhance concerted use of ICTs facilities by fish farmers in their profession. Computer education should be made available to the rural farmers, with emphasis on extension organization. This will help build the capacity of fish farmers and extension officers in the use of ICTs in the study area. 


\section{REFERENCES}

Abubakar, L. and Abdullahi, H.A. (2009). Information and communication technologies in agricultural development in Nigeria: Challenges and opportunities. Proceedings of the 43rd Annual Conference of the Agricultural Society of Nigeria, Abuja. Pp. 715-717.

Adejo, P.E. and Haruna, U. (2009). Access of farmers to ICTs for agricultural development in Bauchi Local Government Area, Bauchi State. Op.Cit. Pp. 704-707.

Akinbile, L.A. (2003). Farmers perception of the effectiveness of Fisheries Extension Extension Systems, Vol. 19, pp.32-44.

Services in Nigeria. Journal of

Akinyemi, O. (1998). Sustainable management of Nigeria's fisheries in the 21st Century. Faculty of Agriculture Lecture Series, No. 7, University of Ibadan. Pp. 39-44.

Arokoyo, T. (2003). ICTs application in agricultural extension service delivery in Nigeria. In; Adedoyin, S.F.(ed) (2005). Agricultural Extension in Nigeria, AESON. Pp. 245-251.

Ayodele, I.A. and Ajani, E.K.(1999).Essentials of Fish Farming. Agape Prints, lbadan. Pp. 39-44.

Bene, C. and Heck, S. (2005). Fisheries and the millennium development goals, solutions for Africa. NAGA World Fish Center Quarterly, Vol. 28, No.384, July-December, pp.14-18.

Technical Centre for Agriculture (CTA) Spore (2004). Information and Communication Technology: Information for agricultural Development in ACP Countries. CTA Spore Magazine, 100: 4-5.

Food and Agricultural Organization (FAO) (2005): Farming Nigeria's Waters. A Compilation of the News Letters of the Aquaculture and Inland Fisheries Project on National Special Programme for Food Security. Vol.1, Nos 1-2, October, 2003-June, 2005. Technical note 16.

Gupta, M.V. (2006). Challenges in sustaining and increasing fish production to combat hunger and poverty in Asia. NAGA World Fish Center Quarterly, Vol. 29, No. 1 and 2, January-June, 7p.

Ifejika, P.I. and Ayanda,J.O. (2006). Status of aquaculture in Kainji Lake Basin of Nigeria. In Ansa, E.J, Anyanwu, P.E and Deekae, S.N. (Editors). Fish for food and income generation in Nigeria. Proceedings of the 20th Annual Conference of Fisheries Society of Nigeria (FISON), Port Harcourt, 14-18 November, 2005, pp. 281-286.

Ifejika, P.I., Akinbile, L.A., Ifejika, L.I. and Oladeji, J.O. (2008). The socio-economic effects on adoption of aquaculture technologies among fish farmers in Anambra State, Nigeria. Journal of Agricultural Extension, Vol. 11, pp. 74-86. 
National Population Commission (2006). National Population Estimates 2006. Abuja, Nigeria.

New Partnersip for African Development (NEPAD) (2005). Fish for All Summit. NEPAD Action Plan for the development of African Fisheries and Aquaculture. Abuja, Nigeria, 23rd August; 24p.

Nkwocha, V.I., Ibeabuchi, I.I., Chukwueke, T.C., Azubuike, N.O. and Nkwocha, G.A. (2009). Overview of the impact of ICT on agricultural development in Imo State, Nigeria. Proceedings, ASN. Op. Cit. Pp. 711-714.

Olapade, O.A., Taiwo, I.O. and Odunaya, O. (2005). A Survey of small-scale Aquaculture Systems in Ogun State. International Journal of Food and Agricultural Research, Vol. 2, No. 1 and 2, pp. 17-25.

Omotayo, O.M. (2005). ICT and Agricultural Extension. In S.F. Adedoyin (Ed). Op.Cit. Pp. 145-157.

Owen,D. (2008). Training workshop on ICT for rural development: Access and application. USAID ICT4D program. Available at: http://go.World bank.org/XL89032600.

Riddler,N. and Hashamunda,N. (2001). Promotion of sustainable commercial aquaculture in sub-Sahara Africa. Vol.1. Policy Framework. F.A.O Fisheries Technical Paper, No. 408/1/ Rome, F. A.O. Pp. 15-17, 32-33.

Shah, P. (2009). Operationalizing ICT in the rural space. Available at: http://web//world bank.org.

Sinkaiye, T. (2005). Agricultural Extension Participatory Methodologies and approaches. In Adedoyin, S.F. (ed). Op. Cit. Pp. 220-233.

Ugwumba, A. and Ugwumba, A. (2003). Agriculture options and the future of fish supply in Nigeria. The Zoologist, Vol. 2, No. 2, pp. 96-122.

http://dx.doi.org/10.4314/jae.v15i1.3

http://dx.doi.org/10.4314/jae.v15i1.3 